\title{
The Macroeconomic Consequences of China's Partially-Reformed Economy
}

The key to eradicating the deflation bias lies in establishing an efficient financial intermediation mechanism

\section{Wing Thye Woo}

\section{(c) OpenEdition}

\section{Journals}

Édition électronique

URL : http://journals.openedition.org/chinaperspectives/686

DOI : 10.4000/chinaperspectives.686

ISSN : 1996-4617

Éditeur

Centre d'étude français sur la Chine contemporaine

\section{Édition imprimée}

Date de publication : 1 décembre 2003

ISSN : 2070-3449

\section{Référence électronique}

Wing Thye Woo, «The Macroeconomic Consequences of China's Partially-Reformed Economy », China Perspectives [En ligne], 50 | november- december 2003, mis en ligne le 05 février 2007, consulté le 10 décembre 2020. URL : http://journals.openedition.org/chinaperspectives/686 ; DOI : https://doi.org/ 10.4000/chinaperspectives.686

Ce document a été généré automatiquement le 10 décembre 2020.

(c) All rights reserved 


\section{The Macroeconomic Consequences of China's Partially-Reformed Economy}

The key to eradicating the deflation bias lies in establishing an efficient financial intermediation mechanism

\section{Wing Thye Woo}

\section{Reading the Macroeconomic Tea Leaves}

1 The annualised growth rate for China in the first half of 2003 was $8.2 \%$ compared with $8.0 \%$ in 2002 , and inflation was $-0.4 \%$ for the first half of 2003 compared with $-1.3 \%$ in $2002^{1}$. Since the growth and inflation rates in the first half of 2002 were still substantially below their respective averages of $9.4 \%$ and $5.5 \%$ during the period 1979-2002, it appears that China's economy is still operating below production capacity $^{2}$. However, there are other indications that overheating might just be round the corner. Data just released on the third quarter of 2003 show that GDP growth had climbed to $9.1 \%$, and that growth in fixed asset investment spending had remained above $30 \%$, a continuation of the higher investment growth that began in the first quarter of 2003. Jonathan Anderson, an economist with the Union Bank of Switzerland, assessed recent growth as understated, saying that "[the] 'true' GDP growth should exceed 11\% in 2003". The perhaps most puzzling part is that the inflation rate has, however, remained at zero ${ }^{3}$.

2 The fact that the macroeconomy's vital signs are ambiguous and are causing confusion among top leaders is very well captured in two newspaper headlines that appeared on two consecutive days in August 2003. On August 18th 2003, an article in the Straits Times of Singapore under the headline "Hu calls for more work creation as jobless rate rises" reported that the Secretary-General of the Chinese Communist Party, Hu Jintao, had called for "stronger measures... [like] fiscal subsidies, tax incentives, insurance subsidies and credit opportunities" to spur economic growth. On August 19th 2003, Hong Kong's South China Morning Post carried an article headlined "Investments soar amid reluctance to rein in growth" which reported that the Chairman of the State 
Development and Reform Commission, Ma Kai, had "urged the nation to be wary of overheating and unveiled measures to cut back lending at state-run banks".

The cost of erring on the overly conservative side is certainly a high one. The official growth target of 7\% in 2003 could create only 10 million new urban jobs, and there are 24 million urban job-seekers ${ }^{4}$. On top of this, 150 million of China's 500 million rural workforce are "effectively" unemployed-and this is the most conservative estimate! ${ }^{5}$ The cost of an overheating could also be major because high inflation in the past has been seen at times to undermine social stability. Furthermore, overheating is a sign that the state credit system has been undermining economic restructuring objectives by bailing out inefficient state enterprises, and funding investments in sectors with excess capacity.

4 As if China's macroeconomic managers are not already sufficiently vexed by the confusing signals of "overheating" and "below-potential growth", they now face tremendous political pressures from Japan, Western Europe and the United States to revalue the renminbi substantially ${ }^{6}$. The current round of external indignation over an undervalued renminbi was set off on December 1st 2002 when two senior officials of Japan's Ministry of Finance wrote in the Financial Times that "China is exporting deflation... through export growth and a combination of price deflation and an exchange rate pegged to the dollar", and they asked China "to allow the currency to appreciate"7. By mid-2003, South Korea, Western Europe and the United States have joined Japan in urging an appreciation of the renminbi to reduce unfair competition from cheap Chinese imports ${ }^{8}$. How China will respond to this foreign clamour for revaluation of the renminbi will, not surprisingly, depend on its diagnosis of the current macroeconomic situation. If Chinese leaders conclude that deflation is a more probable threat to China's economic growth than overheating, then there would at most be the introduction of a minor trading band around the current renminbi-US dollar exchange rate. 
Table 1 : Output growth and inflation performance in China (1979-2003)

\begin{tabular}{|c|c|c|c|}
\hline & $\begin{array}{l}\text { Gross } \\
\text { Domestic: } \\
\text { Product }\end{array}$ & $\begin{array}{l}\text { Retail } \\
\text { Price: } \\
\text { Index }\end{array}$ & $\begin{array}{l}\text { Consumar } \\
\text { Price } \\
\text { Index }\end{array}$ \\
\hline & \multicolumn{3}{|c|}{ Rate of change (6) } \\
\hline 1979 & 7.6 & 20 & $=$ \\
\hline 1980 & 7.8 & 6.0 & $=$ \\
\hline 1981 & 5.2 & 24 & . \\
\hline 1982 & 9.1 & 1.9 & $=$ \\
\hline 1983 & 109 & 1.5 & . \\
\hline 1984 & 15.2 & 28 & - \\
\hline 1985 & 13.5 & 8.8 & 93 \\
\hline 1986 & 8.8 & 6.0 & 6.5 \\
\hline 1987 & 11.6 & 7.3 & 7.3 \\
\hline 1988 & 11.3 & 18.5 & 18.8 \\
\hline 1989 & 4.1 & 17.8 & 18.0 \\
\hline 1990 & 3.8 & 21 & 3.1 \\
\hline 1991 & 9.2 & 29 & 3.4 \\
\hline 1992 & 14.2 & 5.4 & 6.4 \\
\hline 1993 & 135 & 13.2 & 14.7 \\
\hline 1994 & 12.6 & 23.7 & 24.1 \\
\hline 1995 & 10.5 & 14.8 & 17.1 \\
\hline 1996 & 9.6 & 6.1 & 8.3 \\
\hline 1997 & 8.8 & 0.8 & 28 \\
\hline 1998 & 7.8 & 2.6 & 0.8 \\
\hline 1999 & 7.1 & -3.0 & 1.4 \\
\hline 2000 & 8.0 & 1.5 & 0.4 \\
\hline 2001 & 7.3 & 0.8 & 0.7 \\
\hline 2002 & 8.0 & 1.3 & 0.8 \\
\hline First half of 2003 & 8.2 & -0.4 & 0.6 \\
\hline Averago 1979-2002 & 9.40 & 5.53 & - \\
\hline Average 1979-1996 & 9.92 & 7.84 & 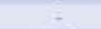 \\
\hline Average $1997-2002$ & 7.83 & -1.39 & 0.16 \\
\hline \multicolumn{4}{|l|}{ Prodictions for 2003} \\
\hline Anderson (2003) & 11.0 & & \\
\hline Liang (2003) & 8.4 & & 0.9 \\
\hline $\mathrm{Ma}(2003)$ & 8.5 & & 1.2 \\
\hline
\end{tabular}

Sources : China Statistical Yearbook, 2001 and 2002 editions.

5 In assessing what the appropriate stance of macroeconomic exchange rate policies should be, the foremost relevant analytical issue is whether China is already at the "natural" growth rate, i.e. the maximum sustainable output growth rate that is compatible with price stability. The operational difficulty is that the natural growth rate of an economy is not immutable over time, e.g. a change in the rate of technological innovation would change the natural growth rate. In our view, there are two components to understanding China's recent macroeconomic performance.

6 The first component is that the growth of aggregate supply has slowed down since 1997. This view is based on the observation that every growth rate in the 1997-2002 sub-period is below 9.4\%, the average annual growth rate in 1997-2002. This extended period of below-average growth is unprecedented in China's market reform, which suggests that the slower growth phase near the end of the 1990s is the result of China having largely exhausted the growth potential created by the economic deregulation and internationalisation. Our interpretation of a growth slowdown upon economic maturation is based on our more general view that the impressive post-1978 growth of China was generated by the steady convergence of a formerly autarkic developing country to the frontier of modern science ${ }^{9}$. The closer to the world science frontier, the lower the catch-up rate of growth-which is consistent with the slowing down of the average growth rate in the $1979-96$ sub-period from $9.9 \%$ to $7.8 \%$ in the $1997-2003$ subperiod. 
Table 2 : Investment trends by ownership (as \% of GDP)

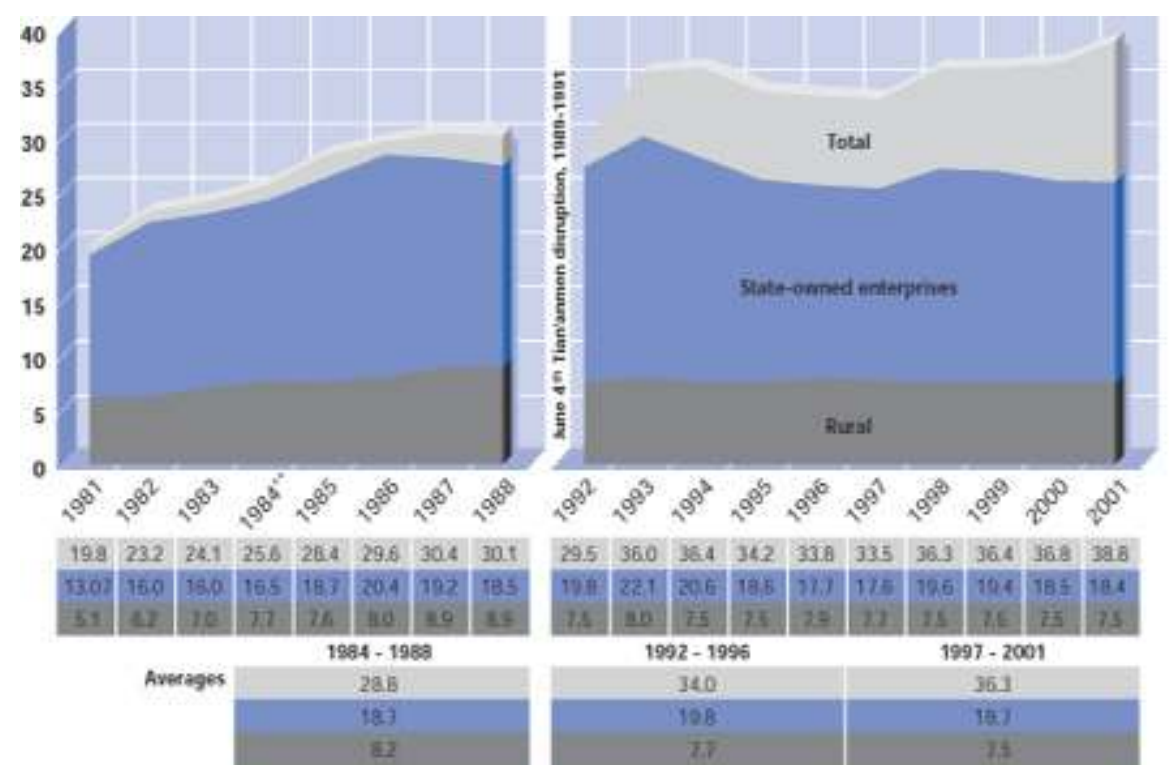

NB: Investment refers to fixed asset investment.

1984 was the year that the central government gave the clear signal that it had no ideological objection to the formation of rural enterprises.

Rural = rural collectives and rural individuals.

State-owned entreprises do not include state-controlled units listed under varions typs of joint-owned units (e.g. share-holding units, joint ventures units).

Sources: China Statistical Yearbook, compiled from varions annual editions

The second component of our explanation of recent macroeconomic performance is that there was also a large downward shift in the inflation rate between the two subperiods, an annual average of $7.8 \%$ in $1979-1996$ versus $-1.4 \%$ in $1997-2002$. Clearly, there must also have been a slowdown in the growth of aggregate demand because in the absence of a drop in aggregate demand growth, a fall in supply growth (as identified above) would have produced an outcome of lower growth-cum-higher inflation (i.e. stagflation) rather than the observed outcome of lower growth-cumdeflation. More precisely, the lower growth-cum-deflation phenomenon in the 1997-2002 sub-period means that the slowdown in aggregate demand growth was greater than the slowdown in supply-side growth. In the next section, we will develop the argument that China's dysfunctional banking system has created a deflationary bias in the economy.

The Retail Price Index (RPI) showed a price deflation in October 1997, as did the Consumer Price Index (CPI) in February 1998. When it became apparent by the middle of 1998 that the economy was slowing down significantly, the government began to implement monetary and fiscal measures to boost aggregate demand. The interest rate has been reduced eight times in less then six years, with the latest rate cut on February 21st 2001, which brought the one-year deposit rate to $1.98 \%$ and the one-year lending rate to $2.34 \%$. After the jump in government spending the fiscal deficit increased substantially from $1.1 \%$ of GDP in 1998 to $1.9 \%$ in $1999,2.5 \%$ in $2000,2.7 \%$ in 2001 and $2.9 \%$ in $2002^{10}$. Most government economists, e.g. Jia ${ }^{11}$, believe that the investment using funds raised through treasury bond issuance contributed about two percentage points to GDP growth each year in the 1999-2002 period. 
With the encouragement of the central bank, especially with the onset of SARS in early 2003, the state banks greatly expanded their loans, especially to the real estate sector, and money growth went from $16.8 \%$ in the fourth quarter of 2002 to reach $20.0 \%$ in the second quarter of 2003. The combination of additional fiscal and monetary stimulus to offset the deleterious effects of SARS on aggregate demand caused the rate of fixed asset investment to jump from $21.6 \%$ in the fourth quarter of 2002 to over $30 \%$ in the first three quarters of 2003. ${ }^{12}$ The unfortunate feature about encouraging SOE investments, as emphasised by Fan and Woo ${ }^{13}$, is that, in a partially-reformed centrallyplanned economy, there are many institutional features that motivate SOE investments to veer out of control frequently, and overheat the economy as a by-product-which might be beginning to happen in the second half of 2003.

The Deflationary and Current Account Consequences of Inadequate Financial Intermediation

10 At a superficial level, the systemic deflationary pressures that have plagued China since 1997 have their sources in, one, a shrinking money multiplier (a phenomenon that many Chinese economists have called "the liquidity trap"), and two, a slowing down in the growth of consumption (a phenomenon commonly known as "the paradox of thrift"). ${ }^{14}$ China has tried to boost the domestic economy with successive cuts in interest rates, but the rise in credit creation has been much lower than expected, except for the periods when the central bank leaned heavily upon the banks. ${ }^{15}$ The paradox of thrift refers to the low level of private aggregate demand because the private saving rate has been increasing. The saving rate went from almost $20 \%$ of GDP in 1981 to $30 \%$ in 1988 , and to almost $40 \%$ in 2001.

11 At a deeper level, however, both of these phenomena, we suggest, spring from the same cause, which is the absence of adequate financial intermediation in China. The liquidity trap made its appearance in the mid-1990s when Zhu Rongji decreed the removal of the state bank manager if the ratio of non-performing loans (NPL) in the bank were to go up two years consecutively. As the majority of state enterprises are either in the red or just breaking even, the banks became unwilling to lend money to the state-owned enterprises. Lending more to private enterprises is not really a good option because, one, their legal status is lower than that of state enterprises, and, two, there was no reliable way to assess their balance sheets. The only activity that the banks are happy to allocate their funds to is the purchase of state bonds, i.e. the financing of the government's deficit. ${ }^{16}$ The elimination of the liquidity trap requires that the state removes the barriers to lending to the private sector by ending legal discrimination against them, and establishing uniform accounting and auditing standards that have credible enforcement mechanisms.

In discussions on the rise of the savings rate, a common view is that the rise reflects the uncertainty about the future that many SOE workers feel in the face of widespread privatisation of loss-making SOEs. We find this explanation to be grossly incomplete because there has also been a rise in the rural saving rate even though rural residents have little to fear about the loss of jobs in the state-enterprise sector because none of them are employed there. Based on the work of Liu and $\mathrm{Woo}^{17}$ on savings behaviour, we conjecture that the desire to invest is an important reason for why the rural sector has increased its savings rate. The most dynamic industrial expansion in China in the 1984-1994 period occurred in rural areas. Since non-state firms in rural areas could not borrow from banks, the only way they could establish themselves was through self- 
financing, which required the would-be entrepreneurs to save first. In the very first phase of rural industrialisation, the amount of capital needed to start a factory workshop was very low. After a decade of rapid industrial growth, the Chinese countryside is saturated with labour-intensive enterprises. As competition among rural enterprises is very fierce at present, it no longer makes economic sense to invest and open the same type of factory workshop. Rural enterprises must therefore move up to the next stage of value-added production in order to be more profitable. This new generation of rural enterprises is much more capital-intensive, and thus requires a much larger amount of start-up funds. And rural residents have responded to the higher capital requirements by increasing their saving rates.

Since the phenomenon of investment-motivated saving must also be present within the Chinese urban community the usual pessimism-based explanation for the rise in the urban savings rate is only partially correct. In fact, with the steady relaxation of regulations against the establishment of private businesses in the rural and urban areas, the amount of investment-motivated savings in China could only have risen more. To sceptics of our investment-motivated savings hypothesis, we want to point out that Jeffrey Williamson ${ }^{18}$, an economic historian, has summed up the historical record of Western Europe and North America as showing that "investment demand seems to have been the driving force behind private saving and accumulation, past and present" ${ }^{\prime \prime}$.

Table 2 reports the investment trends in China in the post-1978 era. Total fixed investment has increased as a proportion of GDP: an annual average of $28.8 \%$ in $1984-88,34.0 \%$ in $1992-1996$, and $36.3 \%$ in $1997-2001$. SOE investment went up in the period 1992-96 (19.8\%) and then returned to the initial 1984-88 level (18.7\%). We are of the opinion, however, that the amount of state-directed investment in the 1997-2001 period could be more than three percentage points higher than $18.7 \%$ of GDP because many of the big SOEs in 1988 had by 1999 converted themselves (or components of themselves) to share-holding companies listed on the stock exchanges-while remaining state-controlled. Furthermore, many SOES have formed joint-venture firms with domestic and foreign companies, with themselves as the controlling shareholders.

Table 3. Rising fragility of China's banking sector

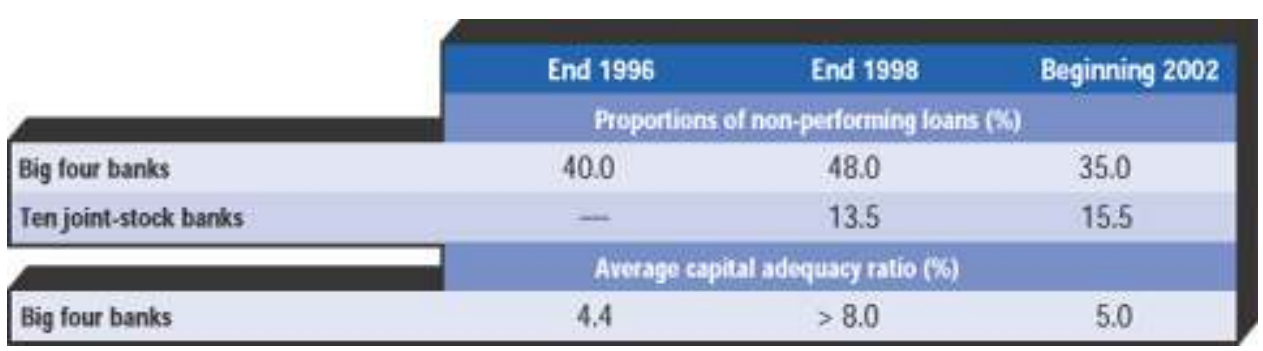

NB: Proportion of non-performing loans for the four major banks for 1996 and 1998 are re-estimated, based on new information made available at the beginning of 2001. The proportion for 2001 excludes the renminbi 1.4 trillion transferred to the Asset Management Companies in the previous year. Source: Citigroup, 2002, estimates.

Contrary to the rise in total investment and the likely rise in state-directed investment, rural investment has fallen from $8.2 \%$ in $1984-88$, to $7.7 \%$ in $1992-96$, and then to $7.5 \%$ in 1997-2001. Our hypothesis is that a major reason for the decline in the rural investment ratio is that the traditional labour-intensive factory is no longer profitable, 
and rural entrepreneurs have been unable to borrow the money to undertake the more capital-intensive investments required for the next generation of rural enterprises ${ }^{20}$. The investment-GDP ratio went up at the national level because FDI rose while state investments (through the budget, state-owned enterprises, and state-controlled enterprises) utilised the higher domestic savings fully.

We now turn to show that another outcome of inadequate financial intermediation is a chronic current account surplus. To see this point, consider the following accounting relationship: ${ }^{21}$

(current account surplus) = (government budget surplus) + (savings of SOES investments by SOEs) + (savings of the non-state sector - investments of the non-state sector)

17 The facts for the recent period are that the current account surplus (or, loosely speaking, the trade surplus) is positive, the government budget surplus is negative at an unprecedented level, and SOE savings are lower than SOE investments. This means that the savings of the non-state sector must greatly exceed the investments of the non-state sector. As documented earlier, the government has sought to fight deflation by increasing public works (i.e. running record budget deficits) and encouraging SOE investments to soak up the excess savings. The rise in total investments has not been sufficient to use up the excess savings, however, and these residual excess savings have leaked abroad in the form of an aggregate trade surplus. Inadequate financial intermediation has made China a capital exporting country!

This perverse current account outcome is not new. Taiwan had exactly this problem up to the mid-1980s when all Taiwanese banks were state-owned and were operated according to civil service regulations, which required the loan officer to repay any bad loans that he had approved. The result was a massive failure in financial intermediation that caused Taiwan's current account surplus to be 21\% of GDP in 1986.

China's proclivity to generate persistent current account surpluses has managed to manifest itself only after 1994 because of major policy changes implemented in that year. Before 1994, with the government budget deficit being usually small, the voracious absorption of bank loans by SOEs, in the soft-budget environment, to invest recklessly kept the current account usually negative. In 1994, Zhu Rongji implemented stricter controls on the state-owned banks (SOB) to reduce the then $24 \%$ inflation rate and the explosion of NPLs. This lower growth rate in SOE investments from 1995 onward is the reason why China's built-in propensity towards a current account surplus came to light only after 1995. The pronounced tendency towards higher current account surpluses is mainly caused by the rise in the savings of the non-state sector for the reasons we identified earlier, e.g. rise in the required amount of start-up capital, improvement in the official attitude to market capitalism. ${ }^{22}$ The reason why China is not producing the gargantuan current account surpluses seen in Taiwan in the mid-1980s is because of its record budget deficit and the still excessive amount of SOE investments.

20 Obviously, increasing budget deficits and SOE investments to counter deflation and reduce the trade surplus can only be a satisfactory solution in the short term. In the long term, the increased public investments could follow an increasingly rent-seeking path that is wasteful, as in Japan (e.g building a second big bridge to a low-populated island to benefit a politically-connected construction company), and the increased SOE investments could convert themselves into NPLs in the SOBs. The right solution to the 
problem of excess savings is not for the government to absorb them by increasing its budget deficit but to establish an improved mechanism for co-ordinating private savings and private investments. This solution is correct regardless of the veracity of our hypothesis about investment-motivated savings. We will argue later in the paper that the formation of domestic private banks and the entry of foreign banks will correct the problem of inadequate financial intermediation, and eradicate the deflationary tendencies created by the liquidity trap and the paradox of thrift. The fact is that the present banking system is a sinkhole, a situation that we will examine now.

The critical situation of China's banking system

In 1997-98, the government injected new capital into China's banks and transferred a large proportion of the NPLs to the state-owned asset management corporations (AMCs). These actions raised the capital adequacy ratio (CAR) of the four largest SOBs from $4.4 \%$ at the end of 1996 to over $8 \%$ at the end of 1998 , see Table 3. However, the rapid appearance of new NPLs after 1998 lowered the average capital adequacy ratio of the four largest SOBs to $5.0 \%$ by the beginning of $2002 .{ }^{23}$ The banking reform efforts of the past several years have failed, and the state banks are now in need of another round of recapitalisation..$^{24}$

In this situation of a fragile banking system, China has committed itself to opening up the banking system completely within five years of joining the World Trade Organisation (WTO), which it did in December 2001. Foreign banks could conduct transactions in foreign currencies from the beginning of WTO membership, conduct transactions with the local corporate sector in renminbi after two years, and conduct transactions with local households in local currencies after five years. Although foreign banks are likely to compete only in the coastal cities, at least in the initial period, the pressure on domestic banks can be high, as the big four banks extract about $95 \%$ of their profits from about half a dozen coastal cities (Shanghai, Peking, Xiamen, Shenzhen, Guangzhou and Tianjin). Because there is no depositor insurance in China, the obvious question is whether depositors will believe that these foreign banks will drive the SOBs into open bankruptcy, and hence rush to withdraw their savings from the SOBs, setting in motion the vicious downward spiral of credit contraction leading to business failures, rendering sound financial institutions insolvent, and contracting credit further.

Our reading is that even if pressures on the state banks do occur through depositor withdrawals, there is unlikely to be a full-blown crisis because the central bank will be able to issue currency to the state banks to meet the withdrawals. This expansion of high-power money cannot be easily translated into a loss of foreign reserves because capital controls, which we support, remain in place and are likely to do so for the foreseeable future. The resulting expansion of high-power money will also not have much impact on inflation because this is mainly a shift out of bank deposits into cash, or from some banks to others, and not a shift into goods. In fact, in the present deflationary atmosphere, a run from bank deposits to goods is a macroeconomically stabilising development! Simply put, the government has the technical ability to accommodate shifts in bank deposit preferences, even a modest bank run, without risking exchange rate collapse or runaway inflation.

One could therefore argue, as Fan has ${ }^{25}$, that if the Chinese government decides to keep the SOBs as the dominant financial intermediation mechanism, then the SOBs should not be re-capitalised again. The effective way to slow down the pace of NPL creation in 
an SOB-dominated financial system and keep the fiscal situation sustainable is to keep the NPLs on the books of the SOBs, with "the financial status of these loans... constantly watched and openly discussed" in the public media. We think, however, that Fan Gang's solution can be a medium-term solution at best. In our assessment, China's WTO accession has made recapitalisation of the SOBs inevitable in the coming decade. This is because the large amount of NPLs in the SOBs means that they have much higher operating costs than the foreign banks. SOBs have to pay interest on the deposits that are the counterparts of the bad loans, whereas all the loans of the foreign banks (at least in the beginning) will be serviced. With the foreign banks being able to afford to pay higher deposit rates and to charge lower lending rates, the demise of the SOBs seems inevitable unless their NPL burden is removed. ${ }^{26}$

In order for Fan Gang's suggestion of no recapitalisation to work at all, it is necessary that the foreign banks (which will no longer face more restrictions than Chinese banks by 2007), will not expand aggressively out of the big coastal cities to blanket the rest of the country with branches in a short period of time. Our guess is that Fan Gang's method can work for about seven to ten years because we think that only HSBC and Citibank are likely to actively expand their banking network in China in the next decade, and even then mostly in the major coastal provinces.

The most important priority for financial sector reform is the appearance and growth of competitive domestic private banks. As China is required by its WTO accession agreement to allow foreign banks to compete against its SOBs on an equal basis by 2007, it would be akin to self-loathing not to allow the formation of truly private banks of domestic origin. There is no reason to favour foreign private banks over domestic private banks, and no reason why China should not allow its best financial minds to compete with, and achieve the same glorious success of, the best foreign financial minds. We therefore recommend that, right after the recapitalisation of the big four state banks, at least two of them be broken into several regional banks, and that the majority of these regional banks be privatised. ${ }^{27}$ At the same time, the laws on the establishment of new banks should be loosened, and interest rates deregulated. However, it is most crucial that liberalisation of the financial sector proceeds no faster than the development of the financial regulatory ability of the state. Even then, the danger of substituting financial crash for financial repression is still a real one. A modern financial system requires a modern system of financial supervision and prudential regulation for its proper functioning.

It would be a good idea to sell a few of the regional state banks to foreign banks. This will facilitate the transfer of modern banking technology to Chinese banks. The more local staff the foreign bankers train, the larger the pool of future managers for Chineseowned banks. An accelerated process of promoting the growth of sound domestic private financial institutions and allowing the entry of foreign financial institutions would certainly shorten the time it would take for Shanghai it to assume its rightful place among the major international financial centres, and to contribute to more efficient intermediation of the world's savings.

We should mention that entry of Western banks into China's financial markets is not the same thing as liberalisation of the capital account in the balance of payments. We do not believe that China would be well served by a rapid opening of the capital account, since that could subject China to rapid swings of short-term capital in the same manner that has whipsawed the economies of South-East Asia and Latin America. 
Just as in financial market liberalisation, capital account opening should also proceed gradually and in stages, because it must be accompanied by sophisticated financial market regulation, something that is clearly not in place at this time. The fact is that foreign banks could suddenly become conduits for large-scale capital flight, or for rapid swings in short-term lending and repayments, or facilitators of bank runs (in which depositors do not merely switch banks, but actually switch to a foreign currency or foreign assets).

The precarious fiscal position of the state

Since the government recapitalised the banks in 1998, and needs to do again now, the important question is how many more rounds of bank recapitalisation can China afford without generating a fiscal crisis? The simple fact is that fiscal sustainability lies at the heart of whether a banking crisis would actually occur. As long as the state is perceived to be able and willing to bail out the SOBs, depositors would retain their confidence in the SOBs regardless of the actual state of their balance sheets.

The stock of publicly-acknowledged government debt comes to only $16 \%$ of GDP, and so it is usual to hear official assurances that the current fiscal deficits of less than $3 \%$ of GDP do not pose a problem for debt servicing by the state. However, the analytically correct measure of public debt is the consolidated debt of the state sector, which would include at least some part of the contingent liabilities (e.g., foreign debts of SOEs and SOBs, and unfunded pension schemes in the SOE sector) that the state might have to assume responsibility for when the state-owned units default on their financial obligations. We should note that if an analyst counts NPLs as contingent liabilities, then they are really computing what the public debt will be after one more round of bank recapitalisation, i.e. the second bank recapitalisation. According to $\mathrm{Fan}^{28}$, the consolidated public debt at the end of 2001 was $72 \%$ of GDP; and according to Citibank ${ }^{29}$, it could be as high as $115 \%$. So is China's present debt-GDP ratio too low or too high?

31 To answer this question, we note that the central government debt-GDP ratios in Italy, Sweden and the United States were, respectively, $117.6 \%, 70.8 \%$ and $50.5 \%$ in $1995^{30}$. So if China does undertake its second bank recapitalisation since 1997, its public debt will still be within the range seen in advanced OECD countries that are not experiencing fiscal crises. However, there are two important points to be made to show that this finding is not an optimistic one.

First, the forthcoming recapitalisation of China's banks appears to be the last major one that the government could implement in the short-term without risking the stability of the domestic financial markets and its credit standing in the international financial markets. A third recapitalisation will push the debt-GDP ratio to over $150 \%$, well above the OECD norm.

Second, if China recapitalises the SOBs a second time, then it will have to compromise the expansionary fiscal policy that has been keeping GDP growth above 7\% since 1997. This is because China raises much less state revenue, as a share of GDP, than the OECD countries, and hence has a much lower capacity to service its public debt. The revenueGDP ratio was $16.2 \%$ for China in 2001, 30\% for Italy in 1995, 38\% for Sweden in 1995, and $21 \%$ for the United States in $1996 .{ }^{31}$ The additional debt service from the second bank recapitalisation will be about $1.5 \%$ to $2.5 \%$ of GDP. ${ }^{32}$ If China increases tax collection or reduces infrastructure spending to cover this increased debt service, then this second recapitalisation of the SOBs will reduce the fiscal stimulus that has been keeping the GDP growth rate above $7 \%$. Between these two options, expenditure 
reduction cannot be considered the less likely outcome because China's experience in the reform era is that frequent changes to the tax system have not been able to raise revenue significantly for a sustained period. The reason for the low revenue-GDP ratio could be because increasing tax collection is as much a political challenge as it is an administrative challenge. ${ }^{33}$

In summary, China's consolidated debt-GDP ratio will be relatively high by international standards after a second bank recapitalization, while its revenue-GDP ratio will remain relatively low. The greatest threat to the stability of China's financial market is fiscal sustainability, and the biggest threat to fiscal sustainability is successive rounds of bank recapitalisation. This precarious outcome is a systemic feature of the current banking system, a relic from the era where central planning was the preferred engine of economic growth. Of course, we cannot attribute the creation of NPLs entirely to the SOBs, their chief customers, the SOEs, deserve an equal share of the blame. The fact is that without solving the SOE problem, the problem of NPLs cannot be solved.

The failure of the latest reform in the state enterprise sector

We must emphasise that the inflationary problem generated by the traditionally biggest macroeconomic destabiliser-the SOE sector-still exists. If anything, the SOE sector in 2003 has not only become a source of potentially bigger macroeconomic instability, it has also emerged as a source of socio-political instability. To see the origin of these negative developments, we review the Fan and Woo (1996) argument ${ }^{34}$ that the reform strategy for the SOE sector during the 1978-93 period was inherently inflationary ${ }^{35}$.

The crux of the 1978-93 SOE reform strategy was to transfer decision-making power from the industrial bureaux to the state enterprises. The increased operational autonomy of the SOEs reduced the ability of the industrial bureaux to monitor the financial situation within the SOEs, and hence created the incentive for SOEs to greatly increase their demand for investment funds. The reduction in bureaucratic oversight of the SOEs in a soft budget environment allowed the SOEs to use creative accounting to privatise profits from good investment projects, and to receive state subsidies to cover losses from bad investment projects. Until about 1996, the SOEs were generally able to satisfy their large appetite for investment because the local governments, in the interest of local development, inevitably lobbied the local branches of the state banks to grant the SOEs' applications for investment loans. The evidence overwhelmingly shows that the local bank branches, at least until 1995, were unable to resist the demand for easy money. ${ }^{36}$

The losses at SOEs exploded after 1992, when mother Russia officially went capitalist, because many Chinese SOE managers saw the same fate for China in the future, and concluded that this was their last chance to steal. As a result SOE losses skyrocketed even though GDP grew in the range of $10 \%$ to $14 \%$ annually in the $1992-95$ period. By 1995, it was common to summarise the SOE situation as one-third of them losing money, and another one-third making no money. From the vantage point of 2003, it seems that continued inefficiency, and de facto asset-stripping and embezzlement of firm profits by managers and workers are the primary causes for the general decline in SOE profits, with the latter being the more important. The devolution of financial decision-making power to the SOEs and the steady reduction in discrimination against the private sector have made it increasingly easy for the managers to transfer state 
assets to themselves. It is hence, perhaps, only natural that of the 327 cases of embezzlement, bribery and misuse of public funds that were tried in Peking in 1999, " $76 \%$ took place in SOEs". ${ }^{37}$

The increasing public outrage over the inequity of the informal privatisation of the SOE sector is well captured in the book by He Qinglian who wrote that the SOE reform has amounted to: "a process in which power-holders and their hangers-on plundered public wealth. The primary target of their plunder was state property that had been accumulated from forty years of the people's sweat, and their primary means of plunder was political power." ${ }^{38}$

The Chinese leadership had, by 1994, recognised the increasingly serious economic and political problems created by the principal-agent problem innate in the decentralisation reforms of Lange-inspired market socialism, and it announced that the clarification of property rights of SOEs would be added into its SOE reform programme. The Communist Party of China (CPC) publicly committed itself in July 1997 to converting most of the SOEs to publicly traded shareholding corporations-a form of industrial organisation that originated in capitalist economies. The 1994-97 decisions to address the loss-making SOE problem more decisively are why employment in manufacturing fell from 98 million in 1995 to 81 million in 2001.

The state's decision in 1997 to accelerate diversification of the ownership structure of the SOEs has to be recognised to be a bold move because the experiences with mass privatisation in Eastern Europe and the former Soviet Union (EEFSU) show that the task is an extremely difficult one and that the outcomes have consistently fallen below initial expectations. For example, in Russia, the "loans-for-shares" privatisation transferred the country's enormous mineral wealth to a group of oligarchs, and the weak administrative and legal structures allowed many managers to take effective control of the privatised firms and loot them instead of improving their operations. Furthermore, the EEFSU experiences warn that mass privatisation is an exceedingly dangerous business politically, no matter how it is done, be it outsider privatisation or insider privatisation. This is because the mass privatisation of SOEs generates so much rent that massive corruption has not been avoided, and the resulting corruption inevitably delegitimises the government, e.g. Vaclav Klaus in the Czech Republic and Boris Yeltsin in Russia.

41 Despite the mediocre to poor privatisation outcomes in EEFSU, privatisation has been going forward in China, albeit with occasional stops, for two main reasons. The first reason comes from John Nellis who points out that "governments that botch privatization are equally likely to botch the management of state-owned firms" ${ }^{39}$. The answer is not to avoid privatisations but to implement more careful privatisations: governments in transition economies should "push ahead, more slowly, with case-bycase and tender privatisations, in co-operation with the international assistance community, in hopes of producing some success stories that will lead by example."

The second reason lies in that the delay of privatisation can be costly to China's government politically. Stealing by managers does occur during privatisation and creates a social backlash against the government, but the maintenance of the status quo has become increasingly difficult because SOE managers in China know from the EEFSU experience that they are in an endgame situation. The widespread spontaneous privatisation by SOE managers could create grave social instability. 
Our opinion is that the solution to the SOE problem in China is not privatisation per se, but a transparent, legal privatisation process that society at large can accept, at the minimum, as tolerably equitable. Because an adequate privatisation programme must compensate the retired and laid-off workers, permit takeover by core investors, and respect the rights of minority shareholders, it is important that legal reforms be carried out simultaneously. Only with a transparent, equitable privatisation process that is overseen by an adequate legal framework, would China be likely to avoid a statecreated Russian-style kleptoklatura that would fuel social dissatisfaction.

Recently, there has been some questioning as to whether the case for privatisation has been overstated. ${ }^{40}$ When Zhu Rongji was appointed premier in 1997, he announced that he would solve the SOE problem in three years. In 2000, he declared victory on the SOE front when the profits of the industrial SOEs leaped from 53 billion yuan in 1998 to 241 billion in 2000. In a careful study, Zhou and Wang quantified the sources of the financial turnaround, and found that ${ }^{41}$ :

the lower interest rate in 2000 increased profits by 52 billion yuan ( $28 \%$ of the increase in SOE profits);

the higher oil prices boosted overall SOE profits by 79 billion yuan because almost all oil companies are state-owned ( $42 \%$ of the increase) ${ }^{42}$ and

the conversion of the bank loans of SOEs into equities held by state asset management companies raised profits by 10 billion yuan ( $5 \%$ of the increase).

About $75 \%$ of the increase in the profits of industrial SOEs in the 1998-2000 period was not due to actions taken within these enterprises but to external factors. When Zhou and Wang calculated the profit rate after deducting the profits from the more favourable external environment, they found that it had increased from $0.7 \%$ in 1998 to $1.2 \%$ in 2000 for the SOE sector, and from $2.8 \%$ to $4.8 \%$ for the non-SOE sector. Despite the recent good news on SOE profitability, the fact remains that the SOE sector still lags considerably behind the non-SOE sector in efficiency. capacity of SOEs to "dissipate rents" through high payments to managers and workers, if not illegal transfer of assets, should remain clearly in the policy-makers' minds. Thus, any gains could well be squandered, if not reversed, in a relatively short period of time. It is hence important for China to replace the present uncontrolled (and uncontrollable) process of asset-stripping in the SOE sector with transparent and equitable privatisation in order to improve macroeconomic stability and to defuse socio-political instability.

We draw four key conclusions from our discussion. First, China's dysfunctional financial system has imparted a deflationary bias to the economy and made China a capital exporting country by constraining the growth of aggregate demand to be less than the growth of aggregate supply. The government has been actively trying to neutralise deflation through an aggressive fiscal policy. We recommend that it should now reshuffle and slightly expand its investment programme to incorporate large import-intensive infrastructure projects so that the current account surplus could be reduced as well. The additional infrastructure construction would create jobs, relieve production bottlenecks, and, on top of that, preserve employment in China's exportoriented sectors. However, the most efficient solution is for private investment rather than public investment to recycle the pool of private savings back into the economy. 
The key to eradicating the deflation bias and the tendency towards current account surplus lies in establishing an efficient financial intermediation mechanism.

51 Second, frequent bank recapitalisation is the biggest threat to China's fiscal solvency. The forthcoming second recapitalisation of SOBs since 1997 is the last one that China can afford. Because fiscal solvency requires that the state keeps interest rates low through regulation in order to contain the cost of debt service, China faces a difficult trade-off between the maintenance of fiscal stimulus to keep growth on track and the promotion of financial market development via bank recapitalisation and interest rate deregulation.

Third, the latest attempt to reform the SOEs has failed. This dismal outcome has been masked by the large profits of the state oil companies resulting from the high price of oil in the recent period. The losses of the non-oil SOEs from continued inefficiency and increased embezzlement constitute a serious threat to sustained high growth, banking sector solvency, price stability, and social stability.

Fourth, while it is important to manipulate aggregate demand via monetary-fiscal policies to keep the actual growth rate close to the natural growth rate, China is in the fortunate position that it can implement other economic policies that will increase the natural growth rate. To use a production analogy, the biggest gain comes not only from keeping an engine running at peak efficiency but also from having the engine with the largest capacity. In short, the most important economic task for China is to adopt the best economic growth engine that world economic history has identified: a market economy where competitive private enterprises constitute the norm, and where the state focuses mainly on the provision of public goods and social insurance. The switch to the new growth engine necessitates that China continues the privatisation of nondefence-related state enterprises that are not natural monopolies, begins the privatisation of SOBs, and reduces drastically the legal discrimination against the private sector.

\section{NOTES}

1. This paper is part of an ongoing project on Economic Growth in China conducted by the East Asian Program of the Center for Globalization and Sustainable Development at Columbia University. I am grateful to Jonathan Anderson, Martin Fournier, Fan Gang, He Liping, Huang Yiping, Liang Hong, Ma Jun and Yu Yongding for sharing their insightful analyses on the Chinese economy with me. I am deeply indebted to the Citigroup office in Hong Kong for assistance in data compilation.

2. The inflation rate is calculated from the retail price index (RPI). The average inflation rate according to the consumer price index (CPI) (available from 1985) is $0.6 \%$ for the first half of 2003 and $7.7 \%$ for the period 1985-2002. The CPI is broader than the RPI because it also covers services and housing. GDP growth for the first half of 2003 is from "National economy faces a string of challenges", China Daily, August 26th 2003. 
The 2003 third quarter data are from Jonathan Anderson, UBS Investment Research: Asia Economic Comment, October 20th 2003.

3. The inflation here is calculated from the RPI. The CPI inflation rate was $-0.8 \%$ in 2002 , and its predicted value in 2003 has been put at $0.9 \%$ by Liang (Liang Hong, 2003, Goldman Sachs Asia-Pacific Economic Research: Economic Flash, September 17th 2003, newsletter) and $1.2 \%$ by Ma (Ma Jun, Deutsche Bank: Emerging Markets Monthly, October 3rd 2003, newsletter)-whose respective predicted GDP growth rates in 2003 are $8.4 \%$ and $8.5 \%$.

4. If realised, the official urban employment rate would rise from $4 \%$ at the end of 2002 to $4.2 \%$ at the end of 2003. ("Economy not working hard enough", South China Morning Post, August 16th 2003). However, official data on urban unemployment are well-known for understating the problem. When the official urban unemployment rate was $3.6 \%$ in June 2002, a Chinese Academy of Social Studies report estimated the actual urban unemployment rate to be $7 \%$, and Liu Wei of Peking University estimated it to be $14.6 \%$. See "China jobless figures enter danger zone", Straits Times, June 15th 2002.

5. "Budget and job woes threaten stability", South China Morning Post, December 19th 2002.

6. For example, "Snow calls on Beijing to let currency float", Financial Times, September 2nd 2003.

7. Kuroda Haruhiko and Masahiro Kawai, "Time for a switch to global reflation", Financial Times, December 1st 2003.

8. See, for example, "Behind the debate over China's currency", Barrons, July 28th 2003; "U.S. job losses blamed on China's currency", The New York Times, August 26th 2003; and "Economic ministers discuss Chinese currency", Pacific Business News, July 23rd 2003.

9. Our view that China's impressive growth rate has been generated by its steady convergence to a normal private market economy is contested, however. There is also the popular view that China's growth is the result of successful policy experimentation that has discovered growth mechanisms (most of which are non-capitalist in nature) that are optimum for China's particular circumstances. This convergenceexperimentalist debate is reviewed in Woo Wing Thye, "The Real Reasons for China's Growth", The China Journal, No. 41, January 1999, pp. 115-37, and Woo Wing Thye, "Recent Claims of China's Economic Exceptionalism: Reflections Inspired by WTO Accession", China Economic Review, Vol. 12, No. 2/3 2001.

10. Citigroup has projected the budget deficit to be $2.8 \%$ in 2003 (Citigroup, China Economics 6-Mar-03, newsletter). The scale of the fiscal stimulus has evoked comparisons with the New Deal, and provoked catchy headlines in the media, e.g. "China Gambles on Big Projects for its Stability", New York Times, January 13th 2003, and "Public Spending Explodes", Far Eastern Economic Review, January 30th 2003.

11. Jia Kang, "Fiscal Policy in China after WTO Entry", presentation at the Citigroup Investors' Seminars, Shanghai, May 8th 2002.

12. Employers in SARS-affected areas were also ordered "not to lay off workers"; see "China Tries to Stanch Economic Fallout as Disease, Worry Spread: Emergency Policies Boost Public Spending”, Washington Post, May 9th 2003.

13. Fan Gang and Wing Thye Woo, "State Enterprise Reform as a Source of Macroeconomic Instability", Asian Economic Journal, Vol. 10, No. 3, November 1996, pp. 207-224.

14. Keynes coined both terms. Strictly speaking, the Chinese characterisation of the liquidity trap as a "shrinking money multiplier" does not correspond to Keynes's 
original meaning. Keynes was referring to the situation where the interest rate would not fall despite the addition of reserves because of the overwhelming dominant expectation held by investors that the interest rate would rise soon. In brief, the difference is "the shrinking money multiplier" versus "the non-falling interest rate". 15. For example, during the SARS period, the banks faced intense pressure from the central bank to extend credit.

16. The Chinese government has sought to increase bank lending to private individuals by encouraging banks to establish mortgage loans, which are perceived as less risky because of their seemingly fully collateralised nature. While it is still early to tell, it appears that the enthusiasm for real estate lending in 2002 might have started a speculative bubble in that sector.

17. Liu Liang-Yn, and Wing Thye Woo, "Saving Behavior under Imperfect Financial Markets and the Current Account Consequences”, Economic Journal, Vol. 104, No. 424, May 1994, pp. 512-527.

18. Williamson, Jeffrey, "Comments on Reflections on Development", in Gustav Ranis and T. Paul Schultz (eds.), The State of Development Economics: Progress and Perspectives, Basil Blackwell, NY, 1988, pp. 24-30.

19. For a formal model of investment-motivated savings, and for empirical confirmation of this hypothesis, see Liu Liang-Yn and Wing Thye Woo, "Saving Behavior...", op. cit.; Woo Wing Thye and Liang-Yn Liu, "Investment-Motivated Saving and Current Account Malaise", Asia-Pacific Economic Review, Vol. 1, No. 2, August 1995, pp. 55-68.

20. Woo Wing Thye, "Improving Access to Credit in Rural China," in Baizhu Chen, J. Kimball Dietrich and Yi Feng (eds.), Financial Market Reform in China: Progress Problems and Prospects, Westview Press, Boulder, Colorado, 200, pp. 321-346, presents a proposal of how to meet investment financing needs in rural China.

21. It is important to note that the above equation applies only to China's total trade surplus not to any bilateral trade surplus between China and that country. The equation in standard textbook notation is: $\mathrm{CA}=(\mathrm{T}-\mathrm{G})+(\mathrm{S}-\mathrm{I})$

22. Of course, just as the current account outcome is the product of the three terms in the equation, multi-variable causation also applies to the savings outcome, e.g. demographic features, expected future income growth. Our discussion has concentrated on how one of these variables, the type of financial intermediation mechanism, can affect the savings rate.

23. It is unlikely that the additional post-1998 NPLs were created entirely by new post-1998 loans turning bad, we suspect that a large proportion of them represented pre-1999 NPLs that were not recognised as such in order to hide the seriousness of the problem at the time of the 1997-98 recapitalisation.

24. It should be remembered that the major portion of the NPLs transferred to the AMCs in 1997-98 still needs to be disposed and is thus still the responsibility of the People's Bank of China or the Ministry of Finance. It appears that the AMCs have started by concentrating on the "NPLs with the best prospect for recovery", and that the "average cash-recovery rate" on the small amount processed by June 2002 is $21 \%$. This recovery rate is expected to drop substantially when the more difficult loans are processed. See "On the Road to Ruin", Far Eastern Economic Review, November 14th 2002. 25. Fan Gang, "China's NPLs and National Comprehensive Liability", Asian Economic Papers, Vol. 2, No. 1, 2003, pp 145-152. 
26. To see how NPLs raise the lending rate, we note that the cash-flow constraint that a bank (regardless of solvency) must meet in the absence of state subsidies, of operating costs, and of a required reserve requirement is given by: $r_{D} D=r_{L}[D-N P L]$ where $r_{D}=$ deposit rate, $\mathrm{r}_{\mathrm{L}}=$ lending rate, and $\mathrm{D}=$ amount of deposit. This means that if NPLs equal one-third of deposits, then the lending rate has to be at least $50 \%$ higher than the deposit rate. Since a new bank (domestic or foreign) will not have any NPLs, it can offer better deposit and lending rates than the SOBs.

27. Partial recapitalisation is likely to occur soon, and it is likely that the target would be the reduction of the NPL ratio from $35 \%$ to $15 \%$. The cost is estimated to range from 700 million yuan to 1 trillion yuan ( $7 \%$ to $10 \%$ of GDP)-see "Massive bailout proposed for banks", South China Morning Post, August 26th 2003.

28. Fan Gang, "China's NPLs and National Comprehensive Liability", op. cit.

29. Citigroup, Greater China Insights, June 14th 2002, newsletter.

30. The US ratio is for 1996. Ratios were constructed from the IMF's International Financial Statistics.

31. The revenue-GDP ratio for China is from Deutsche Bank, Emerging Markets Monthly, September 4th 2002, newsletter, which estimated that it will rise to $16.4 \%$ in 2002 and $16.6 \%$ in 2003. Debt to GDP and revenue-GDP ratios for other countries are from the IMF database.

32. This assumes a real bond rate of $4 \%$ to $6 \%$.

33. If the issue of fiscal sustainability is viewed from the broader picture of debt dynamics, one might be tempted to dismiss the existence of a trade-off between bank recapitalisation and fiscal stimulus. Such an optimistic assessment is based on the seeming fulfilment of the technical condition that would allow the high debt-GDP ratio of 115 to be reduced over time or to level off; specifically, China's annual trend growth rate of $8 \%$ exceeds the real interest rate of $4 \%$. However, our calculations show that the existing policies of:a fiscal stimulus that is $2 \%$ of GDP, and an NPL creation rate, ([change in NPL in SOB]/GDP) that is $6 \%$ will produce an internationally unprecedented steady-state debt-GDP ratio of $200 \%$, much higher than the $60 \%$ target that the European Union has set for its members. We therefore doubt the validity of the reasoning behind the optimism.

34. Fan Gang and Wing Thye Woo, "State Enterprise Reform as a Source of Macroeconomic Instability”, Asian Economic Journal, Vol. 10, No. 3, November 1996, pp. 207-224.

35. For an account of the failure of previous SOE reforms, see Huang Yiping, Wing Thye Woo, and Ron Duncan, "Understanding the Decline of China's State Sector", MOCTMOST: Economic Policy in Transitional Economies, Vol. 9, No. 1, 1999, pp. 1-15.

36. The institutional reforms of the central bank and the state banks implemented in July 1993 as part of an austerity campaign have not been successful in changing things. Chen Yuan, Deputy Governor of the central bank, reported that "the enthusiasm for economic growth in some localities is so strong that it is very difficult to stop completely excessive investment financed through forced bank credit" (emphasis added). See Chen Yuan, "Opening Remarks", in Manuel Guitian and Robert Mundell (eds.), Inflation and Growth in China, IMF, Washington D.C., 1996, pp. 23-28. 37. "Judicial Attention to SOEs Pledged", China Daily, February 19th 2000. 38. He Qinglian, Zhongguo de Xianjing (China's Pitfall), Mingjing chubanshe, Hong Kong, 1998. The translated quote is from Liu Binyan and Perry Link, "China: A Great Leap Backward?", The New York Review of Books, October 8th 1998, p. 19. 
39. Nellis John, “Time to Rethink Privatisation in Transition Economies?”, International Finance Corporation Discussion Paper No. 38, World Bank, Washington D.C., 1999.

40. See Nolan Peter and Wang Xiaoqiang, "Beyond Privatization: Institutional Innovation and Growth in China's Large State-Owned Enterprises", World Development, Vol. 27, No. 1, 1999, pp. 169-200, for a recent assertion of a turnaround in SOE performance.

41. Zhou Fangsheng and Xiaolu Wang, "The Way of State Owned Enterprise Reform in China", National Economic Research Institute, Peking, China, 2002, manuscript.

42. This estimate has taken into account the additional production cost of the non-oil SOEs. 